\title{
Data report: permeabilities of Expedition 320 and 321 sediments from the Pacific Equatorial Age Transect ${ }^{1}$
}

\author{
Elizabeth Screaton, ${ }^{2}$ Kusali Gamage, ${ }^{2,3}$ and Stephanie James ${ }^{2}$
}

\begin{abstract}
Chapter contents
Abstract .................. 1

Introduction $\ldots \ldots \ldots \ldots \ldots \ldots \ldots \ldots$

Methods ..................

Results..................... 3

Acknowledgments................ 3

References.....................

Figures................

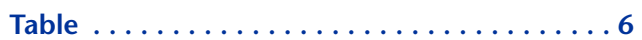

${ }^{1}$ Screaton, E., Gamage, K., and James, S., 2014. Data report: permeabilities of Expedition 320 and 321 sediments from the Pacific Equatorial Age Transect. In Pälike, H., Lyle, M., Nishi, H., Raffi, I., Gamage, K., Klaus, A., and the Expedition 320/321 Scientists, Proc. IODP, 320/321: Tokyo (Integrated Ocean Drilling Program Management International, Inc.). doi:10.2204/iodp.proc.320321.217.2014 ${ }^{2}$ Department of Geological Sciences, University of Florida, Gainesville FL 32611, USA.

Correspondence author: screaton@ufl.edu ${ }^{3}$ Integrated Ocean Drilling Program, Texas A\&M University, 1000 Discovery Drive, College Station TX 77845-9547, USA.

\begin{abstract}
Permeability tests were conducted on seven core samples from Integrated Ocean Drilling Program Expeditions 320 and 321, which investigated the Pacific Equatorial Age Transect. Samples included biogenic sediments as well as clastic sediments. Measured vertical permeabilities vary from $2.1 \times 10^{-16}$ to $1.1 \times 10^{-14} \mathrm{~m}^{2}$. Grain sizes of samples were measured using wet sieving to estimate fraction of sand-sized $(>63 \mu \mathrm{m})$ material and a SediGraph to distinguish silt-sized $(4-63 \mu \mathrm{m})$ and clay-sized $(<4 \mu \mathrm{m})$ particles.
\end{abstract}

\section{Introduction}

Integrated Ocean Drilling Program Expeditions 320 and 321 investigated conditions of the equatorial Pacific during the Cenozoic by recovering cores from a transect (Fig. F1). A secondary objective of the drilling transect was to understand seawater circulation in the sediments and crust. Sediment permeability is an important factor in rates of seawater circulation. In this study, we used flow-through permeability tests to measure the vertical permeability of core samples from Sites U1331-U1333, U1337, and U1338. Grain size analyses were conducted to characterize the fraction of sand-, silt-, and clay-sized particles.

\section{Methods}

\section{Permeability tests}

Permeability tests were conducted using the Trautwein Soil Testing Equipment Company's DigiFlow K (Fig. F2). The equipment consists of a cell (to contain the sample and provide isostatic effective stress) and three pumps (sample top pump, sample bottom pump, and cell pump). American Society for Testing and Materials (ASTM) designation D5084-90 (ASTM International, 1990) was used as a guideline for general procedures. Deionized water was used as the fluid in the pumps, whereas an idealized solution of seawater $\left(25 \mathrm{~g} \mathrm{NaCl}\right.$ and $8 \mathrm{~g} \mathrm{MgSO}_{4}$ per liter of water) permeates the sample. Pressure is transmitted from the deionized water to the permeant across a rubber membrane in an interface chamber (Fig. F2).

The retrieved core samples from Expeditions 320 and 321 were stored in plastic core liners and sealed in polyester film bags to 
prevent moisture loss. The sealed samples were stored in the refrigerator at $4^{\circ} \mathrm{C}$ until immediately prior to sample preparation. All testing was conducted with flow in the vertical direction (along the axis of the core). The permeability testing apparatus accommodates the whole-round core. As a result, disturbance of the sample is minimal relative to testing in which plugs or subsamples are removed from the core. The samples were carefully inspected for cracking or disturbance. Fractured or damaged samples were not tested. To provide freshly exposed surfaces, cores were trimmed on both ends using an Exacto knife, wire saw, or utility knife, depending on core properties. After trimming the ends of the sample, the diameter and height of the sample were measured. The sample was then placed in a flexible wall membrane and fitted with saturated porous disks and end caps. Next, the sample was placed in the cell, which was filled with deionized water. The membrane-encased sample was subjected to the applied pressure of the water in the cell, but fluid exchange occurs only through the flow lines connecting the end caps to the top and bottom pumps. A small confining pressure of $\sim 0.03 \mathrm{MPa}$ (5 psi) was applied, and flow lines were flushed to remove any trapped air bubbles. After flushing the flow lines, the sample was backpressured to $\sim 0.28 \mathrm{MPa}$ (40 psi) in order to ensure full saturation of the sample. Backpressure was achieved by concurrently ramping the cell pressure and the sample pressure to maintain a steady effective stress of $0.03 \mathrm{MPa}$. Once the sample reached saturation, the cell fluid pressure was increased while the sample backpressure was maintained, thus increasing the effective stress on the sample. This effective stress both consolidates the sample and pushes the flexible membrane against the sample to prevent flow bypassing the sample. For comparison with applied effective stresses, the in situ effective stress was computed from the shipboard density measurements (Table T1).

Once the target effective stress was achieved, cell pressure and backpressure were maintained. The sample was allowed to equilibrate for at least $12 \mathrm{~h}$ and generally $24 \mathrm{~h}$. Throughout testing, inflows and outflows to the cell fluid were monitored to assess changes in sample volume, and sample data were recorded every minute. Because fluid pressure in the closed hydraulic system was affected by temperature changes, testing was conducted within a closed cabinet with a fan to keep the internal temperature uniform. Testing temperatures were $28^{\circ} \mathrm{C} \pm 1^{\circ} \mathrm{C}$. Three or more flow tests were performed at each effective stress level, with flow direction varied between tests. Flow tests were run by specifying pressures of the top and bottom pump and allowing flow rates into and out of the sample to equilibrate with time. Equilibration was indicated by inflow equaling outflow.

We used the measured flow rate, cross-sectional area of the sample, and the head difference between the top and bottom of the sample to calculate the hydraulic conductivity using Darcy's law,

$$
Q=-K A(\Delta h / \Delta l),
$$

where

$Q$ = measured flow rate (in cubic meters per second),

$K=$ hydraulic conductivity (in meters per second),

$A=$ the cross-sectional area of the sample (in square meters),

$\Delta h=$ the difference in head across the sample (in meters), and

$\Delta l=$ the length of the sample (in meters).

The hydraulic conductivity values were then converted to permeability ( $k$, in square meters) using the following equation:

$$
k=(K \mu) /(\rho g),
$$

where

$$
\begin{aligned}
& \rho=\text { fluid density }\left(1023 \mathrm{~kg} / \mathrm{m}^{3}\right), \\
& g=\text { the gravitational constant }\left(9.81 \mathrm{~m} / \mathrm{s}^{2}\right) \text {, and } \\
& \mu=\text { viscosity }(0.000857 \mathrm{~Pa} \cdot \mathrm{s}) .
\end{aligned}
$$

The density value was estimated based on literature values for a temperature of $30^{\circ} \mathrm{C}$ and a salinity of $33 \mathrm{~kg} / \mathrm{m}^{3}$ (Chemical Rubber Company, 2012). Assuming a reasonable water compressibility, density change due to the applied pressure is minor $(<0.1 \%)$. The viscosity value was obtained from a synthesis of previous relationships (Sharqawy et al., 2010) for water at $30^{\circ} \mathrm{C}$ and $33 \mathrm{~kg} / \mathrm{m}^{3}$ salinity. A $30 \mathrm{~min}$ or $1 \mathrm{~h}$ interval of stable flow rates was averaged for the permeability calculations, and the standard deviation of the permeability during that interval was calculated to assess uncertainty. The fluctuations in the calculated permeability are likely caused by slight temperature variations. The resulting volume changes would cause temporary changes in measured flow rates. The time interval was selected based on where inflow best matched outflow, indicating steady-state conditions and where the standard deviation was minimized.

For any given sample, permeability was determined at one, two, or three effective stress steps. The corresponding porosity for each effective stress was calculated using the change in volume of fluid $(\mathrm{mL})$ contained in the cell during each consolidation step. Total sample volume $\left(V_{\mathrm{T}(0)}\right)$ was calculated using $\pi r^{2} h$, 
where $r$ is the radius of the core sample and $h$ is the height of the sample. Initial porosities $\left(n_{0}\right)$ for volume calculations were obtained from the shipboard moisture and density results of samples taken adjacent to each permeability sample. We assumed that the porosity of the sample at the end of backpressure is similar to the initial porosity $\left(n_{0}\right)$ of the sample because of the small change in effective stress (0.03 MPa).

Using the initial porosity $\left(n_{0}\right)$, the volume of voids before the testing $\left(V_{\mathrm{v}(0)}\right)$ was calculated using

$$
V_{\mathrm{v}(0)}=n_{0} \times V_{\mathrm{T}(0)} .
$$

Volume of solids $\left(V_{\mathrm{s}}\right)$ was calculated using

$$
V_{\mathrm{s}}=V_{\mathrm{T}(0)}-V_{\mathrm{v}(0)} \text {. }
$$

Using the difference of cell volumes between two consecutive steps (e.g., cell volume at backpressure and cell volume at first consolidation), the change in volume of water in the cell $\left(\Delta V_{\mathrm{T}(1)}\right)$ was calculated. The new total volume of the sample $\left(V_{\mathrm{T}(1)}\right)$ after pore spaces were reduced during the consolidation process was determined by subtracting the change in cell volume at the end of the consolidation step $\left(\Delta V_{\mathrm{T}(1)}\right)$ from the total sample volume $\left(V_{\mathrm{T}(0)}\right)$ using

$$
V_{\mathrm{T}(1)}=V_{\mathrm{T}(0)}-\Delta V_{\mathrm{T}(1)} .
$$

Using the calculated new total volume of the sample $\left(V_{\mathrm{T}(1)}\right)$, the new porosity at the end of the consolidation is calculated. The new porosity $\left(n_{1}\right)$ at the end of the consolidation is

$$
n_{1}=\left(1-V_{\mathrm{s}}\right) / V_{\mathrm{T}(1)} \text {. }
$$

\section{Grain size analyses}

Subsamples for quantitative grain size analyses were extracted in $1.5 \mathrm{~cm}$ thick intervals from the sample after completion of the permeability tests. The subsamples were homogenized and disaggregated. A small aliquot of the homogenized sample was dried to determine water content, which was then used to establish the equivalent dry mass used in the particle size analysis. A sample was disaggregated and wet sieved at $63 \mu \mathrm{m}$ to determine sand-sized fraction. A separate sample was wet sieved at $53 \mu \mathrm{m}$, and material $<53 \mu \mathrm{m}$ was analyzed on a 5100 Micrometrics SediGraph (Coakley and Syvitski, 1991). The Sedi-
Graph data were combined with the wet sieve results to normalize the mud and sand fraction to their relative masses to determine the proportion of sand-, silt-, and clay-sized particles.

\section{Results}

Table T1 summarizes the effective stress and estimated porosity and permeability at each consolidation step as well as the sample's grain size distribution. Measured vertical permeabilities vary from $2.1 \times 10^{-16}$ to $1.1 \times 10^{-14} \mathrm{~m}^{2}$. The lower permeabilities represent sediments rich in clay-sized particles, whereas the higher permeabilities represent sediments rich in silt-sized particles.

\section{Acknowledgments}

This research used samples and data provided by the Integrated Ocean Drilling Program (IODP). The authors thank John Jaeger of University of Florida for expertise and equipment for grain-size analyses. Funding for this research was provided by a Consortium for Ocean Leadership U.S. Scientist Support Program postcruise grant to K. Gamage and National Science Foundation grant EAR-0819769.

\section{References}

ASTM International, 1990. Standard test method for measurement of hydraulic conductivity of saturated porous materials using a flexible wall permeameter (Standard D5084-70). In Annual Book of ASTM Standards: Philadelphia (Am. Soc. Testing Mater.), 63-70.

Coakley, J.P., and Syvitski, J.P.M., 1991. SediGraph technique. In Syvitski, J.P.M. (Ed.), Principles, Methods, and Application of Particle Size Analysis: Cambridge (Cambridge Univ. Press), 129-142. doi:10.1017/

CBO9780511626142.013

Chemical Rubber Company, 2012. Handbook of Chemistry and Physics (93rd ed.): Boca Raton, FL (CRC Press).

Sharqawy, M.H., Lienhard, J.H., V., and Zubair, S.M., 2010. Thermophysical properties of seawater: a review of existing correlations and data. Desalin. Water Treat., 16(1-3):354-380. doi:10.5004/dwt.2010.1079

Initial receipt: 13 February 2014

Acceptance: 18 April 2014

Publication: 18 June 2014

MS 320321-217 
Figure F1. Location of Integrated Ocean Drilling Program (IODP)-US Implementing Organization (USIO) Expedition 320/321 sites.

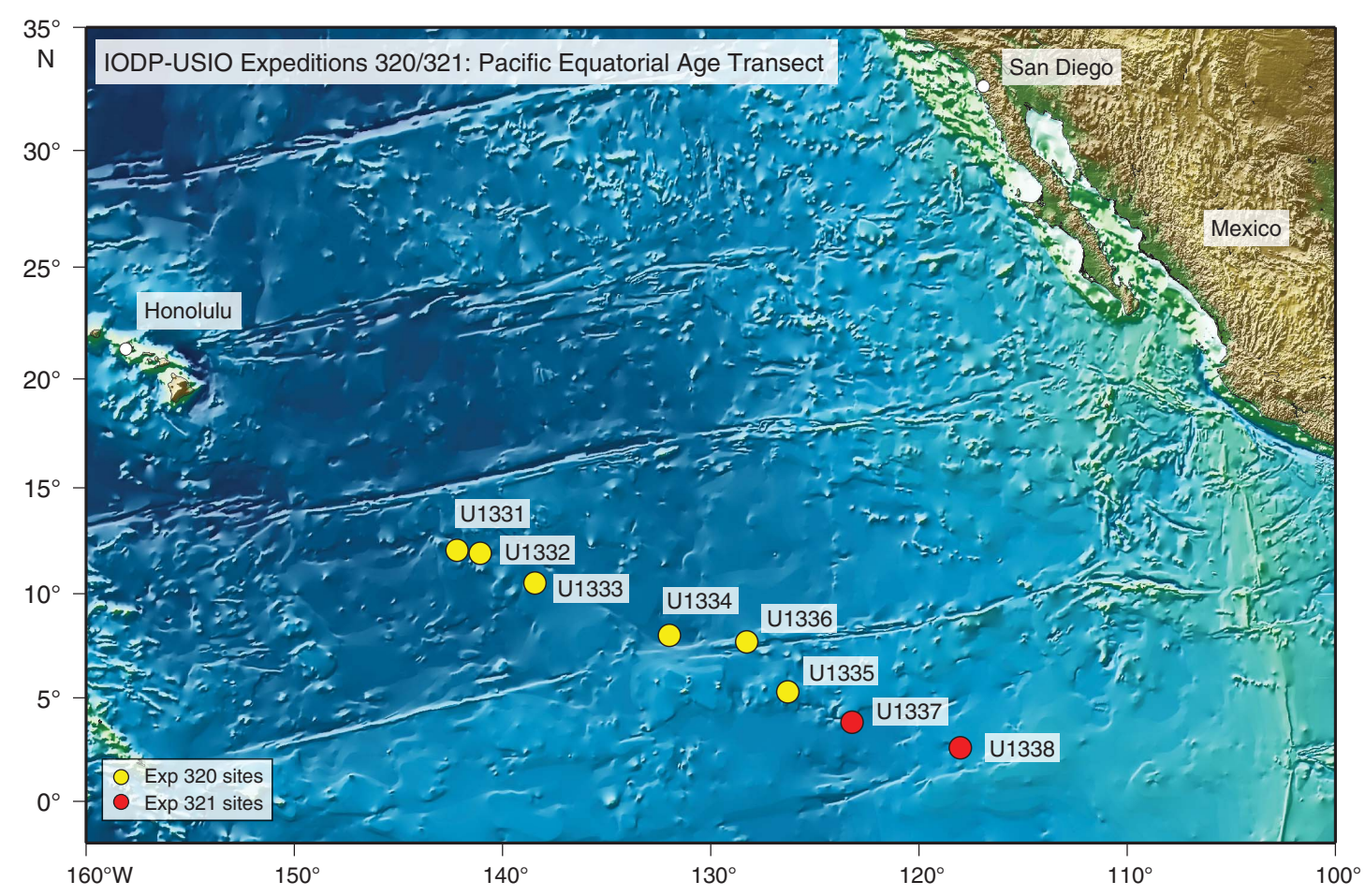


Figure F2. A. Schematic of the permeability test system. B. Permeability test system. The top, bottom, and cell pumps from Geotac consist of $80 \mathrm{~mL}$ pistons that are moved upward or downward to infuse or extract water from the sample or cell. The interface chamber has a rubber diaphragm in the center to separate seawater used as a permeant (bottom chamber) from distilled water used in the pumps (top chamber). Deionized (DI) water was used in the cell pump and sample cell, which has a volume of $2300 \mathrm{~mL}$.

A Bottom pump and pressure transducer

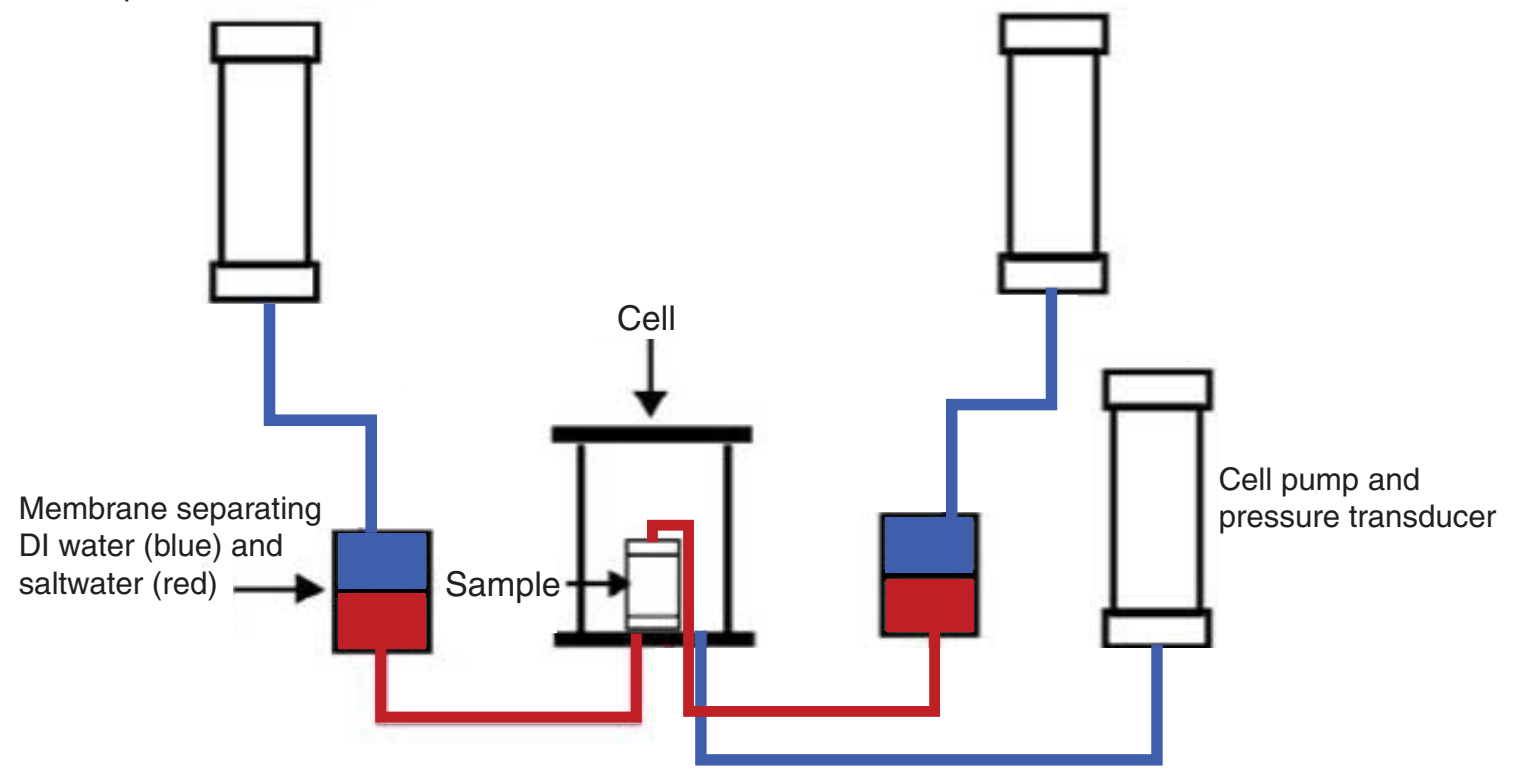

Top pump and pressure transducer

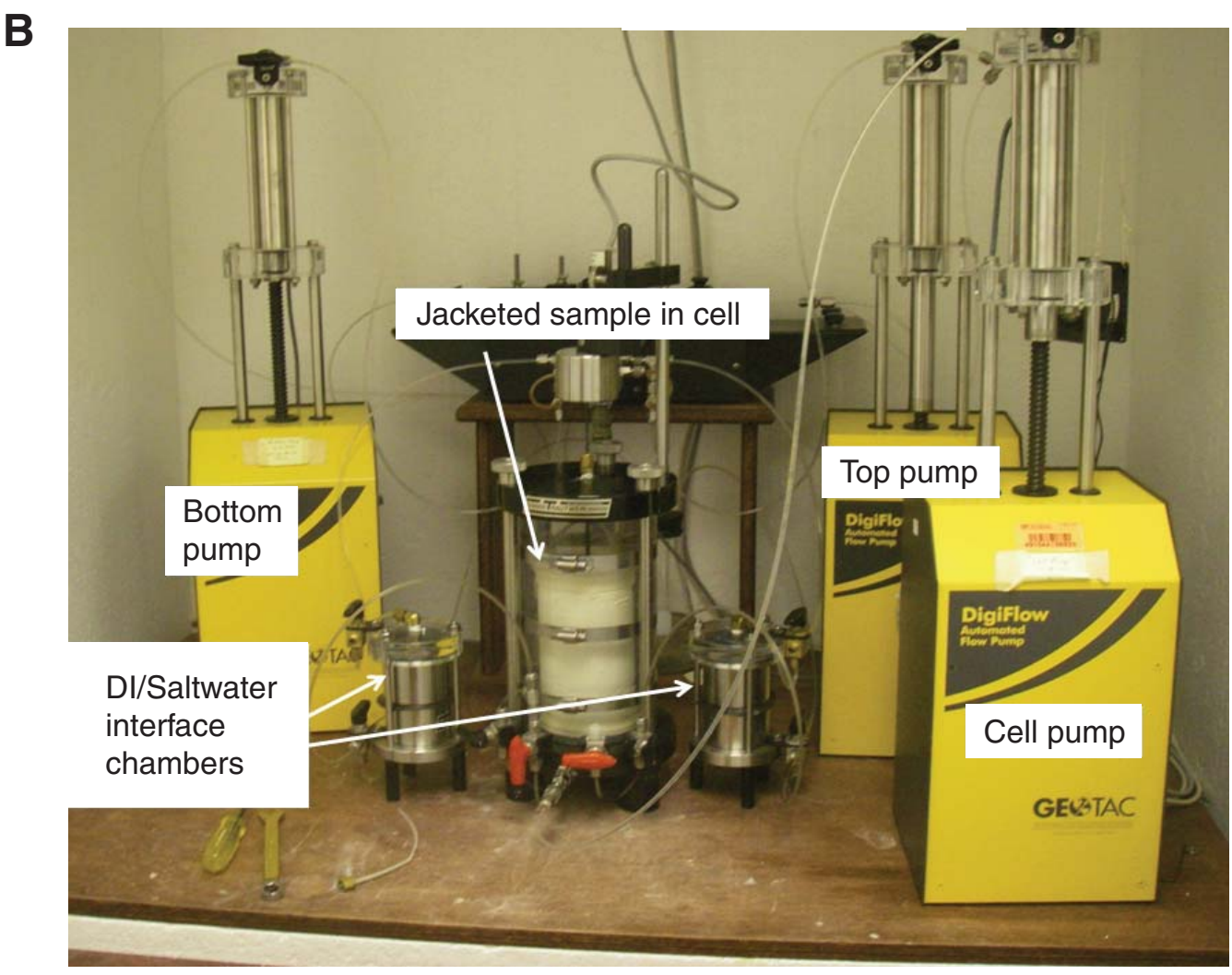




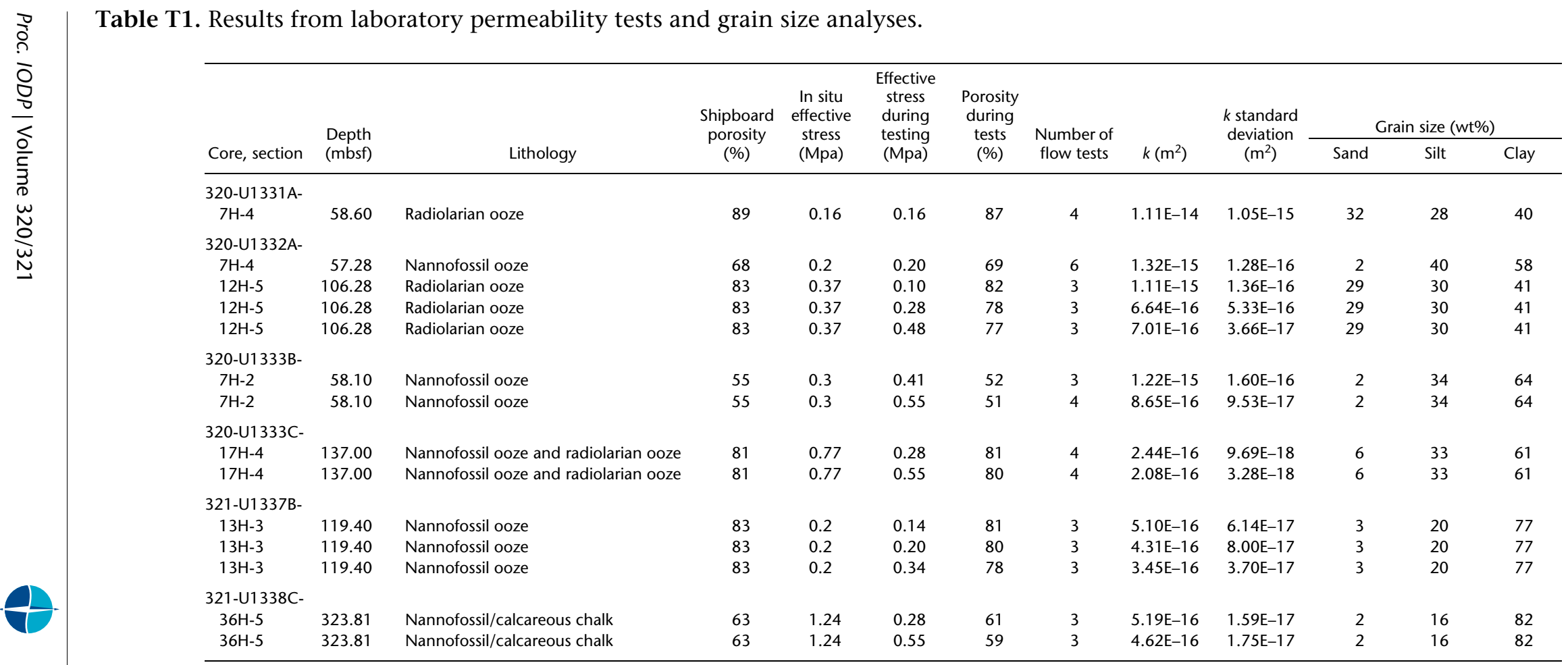

Lithology designations are from the Expedition 320/321 site reports. $k=$ permeability. 